Check for updates

Cite this: RSC Adv., 2017, 7, 38377

Received 27th May 2017

Accepted 25th July 2017

DOI: $10.1039 / c 7 r a 05939 f$

rsc.li/rsc-advances

\section{A microscopic and spectroscopic study of rapid antimonite sequestration by a poorly crystalline phyllomanganate: differences from passivated arsenite oxidation $\dagger$}

\author{
Huawei Wang, ${ }^{\text {ab }}$ Ya-nan Wang, ${ }^{c}$ Yingjie Sun, (D) *a Yiu Fai Tsang, ${ }^{d}$ Daoyong Zhang ${ }^{b}$ \\ and Xiangliang Pan ${ }^{\star b}$
}

During the reaction of arsenite $(\mathrm{As}(\mathrm{III}))$ with $\delta-\mathrm{MnO}_{2}$ (a typically poorly crystalline phyllomanganate), a significant decrease in the oxidation rate is frequently observed, which is mainly attributed to the surface passivation of $\delta-\mathrm{MnO}_{2}$. However, whether surface passivation also occurs during the antimonite (Sb(III)) oxidation process is unclear. In this study, the behavior and mechanisms of $\mathrm{Sb}(\mathrm{II})$ oxidation were compared with those of $\mathrm{As}(\mathrm{II})$ during their reactions with $\delta-\mathrm{MnO}_{2}$. The experimental kinetics results indicated that the oxidation rate of $\mathrm{Sb}(\mathrm{III})$ was 6.14-44.71 times faster than that of As(II) with initial concentrations ranging from 100 to $1000 \mu \mathrm{M}$. The macroscopic and spectroscopic results suggested that surface passivation during the adsorption of $\mathrm{Mn}(\mathrm{II})$ and the formation of $\mathrm{Mn}(\mathrm{II})$ were the predominant causes for the decrease in the As(III) oxidation rate, whereas surface passivation may not have been the limiting factor during $\mathrm{Sb}(\mathrm{II})$ oxidation. Compared to As(III) oxidation, the rapid oxidation of $\mathrm{Sb}(\mathrm{II})$ by $\delta$ $\mathrm{MnO}_{2}$ led to significant changes in the structure and properties of $\delta-\mathrm{MnO}_{2}$, and contributed to the precipitation of $\mathrm{Mn}(\Perp)$ antimonate $\left(\mathrm{MnSb}_{2} \mathrm{O}_{6}\right)$. The results of this study facilitate a better understanding of the environmental behavior of $\mathrm{Sb}$ and $\mathrm{As}$ on metal-oxide surfaces in aquatic environments.

\section{Introduction}

Arsenic (As) and antimony (Sb) are two metalloids that belong to group VA of the periodic table. Elevated levels of As and $\mathrm{Sb}$ in soils and groundwater from geological and anthropogenic sources have attracted worldwide attention due to their high toxicity to humans, plants and microorganisms. ${ }^{\mathbf{1 - 4}}$ The predominant forms of $\mathrm{As}$ and $\mathrm{Sb}$ in contaminated environments are inorganic species. These species are most commonly present in the pentavalent state in the forms of antimonates $\left(\mathrm{Sb}(\mathrm{OH})_{6}{ }^{-}, \mathrm{p} K_{\mathrm{a}}=2.72\right)$ and arsenates $\left(\mathrm{H}_{2} \mathrm{AsO}_{4}{ }^{-}, \mathrm{HAsO}_{4}{ }^{2-}\right.$, and $\mathrm{AsO}_{4}{ }^{3-}, \mathrm{p} K_{\mathrm{a} 1-3}=2.20,6.97$ and 11.53 , respectively) in oxidizing and aerobic surroundings, while in anoxic environments,

${ }^{a}$ College of Environmental and Municipal Engineering, Qingdao University of Technology, Qingdao 266033, PR China. E-mail: yjsun1971@126.com; sunyingjie@ qtech.edu.cn; Fax: +86-532-85071255; Tel: +86-532-85071255

${ }^{b}$ Xinjiang Key Laboratory of Environmental Pollution and Bioremediation, Xinjiang Institute of Ecology and Geography, Chinese Academy of Sciences, Urumqi 830011, PR China. E-mail: xiangliangpan@163.com; panxl@ms.xjb.ac.cn

${ }^{c}$ College of Environmental Science and Engineering, Tongji University, Shanghai 200092, PR China

${ }^{d}$ Department of Science and Environmental Studies, The Education University of Hong Kong, Tai Po, New Territories, Hong Kong SAR, China

$\dagger$ Electronic supplementary information (ESI) available: Additional information is noted in the main text of the current paper including Text S1-S9, Tables S1-S6, and Fig. S1-S6. See DOI: 10.1039/c7ra05939f antimonites $\left(\mathrm{Sb}(\mathrm{OH})_{3}, \mathrm{p} K_{\mathrm{a}}=11.9\right)$ and arsenites $\left(\mathrm{H}_{2} \mathrm{AsO}_{3}{ }^{-}\right.$, $\mathrm{HAsO}_{3}{ }^{2-}, \mathrm{AsO}_{3}{ }^{3-}, \mathrm{p} K_{\mathrm{a} 1-3}=9.22,12.13$ and 13.4) are present in the trivalent state. ${ }^{5}$ As(III) is considered more mobile in soils and sediments than $\mathrm{As}(\mathrm{v})$ because of its weak binding to metal mineral surfaces, ${ }^{6,7}$ and it is also more toxic because it binds to sulfhydryl $(-\mathrm{SH})$ groups, affecting the function of many proteins. $^{8}$ The toxicity of $\mathrm{Sb}$ is similar to that of $\mathrm{As}$, i.e., $\mathrm{Sb}(\mathrm{v})<$ $\mathrm{Sb}$ (III) ${ }^{9-11}$ but its environmental behavior is not as well understood.

The oxidation of $\operatorname{As}(\mathrm{III})$ to $\mathrm{As}(\mathrm{v})$ is an important reaction because this process can decrease not only the mobility of As(III) by increasing its tendency to be absorbed onto mineral surfaces but also its toxicity. ${ }^{\mathbf{1 0 , 1 1}}$ Manganese (Mn) oxides are powerful oxidizing and detoxifying agents, and they can play an important role in many elemental geochemical processes. ${ }^{\mathbf{1 2 - 1 4}}$ The reactivity of $\mathrm{Mn}$ oxides varies with their mineralogy, and previous studies have suggested that layered Mn oxides (i.e., phyllomanganates) are more reactive than Mn oxides with tunnel structures (e.g., pyrolusite and romanechite). ${ }^{15,16}$ Due to their high specific surface areas and structures with highly reactive vacancy sites, these phyllomanganates can absorb metals, such as $\mathrm{Zn}$ (II), $\mathrm{Cu}$ (II), $\mathrm{Pb}$ (II) and Ni(II). ${ }^{17-19}$ However, these materials can also readily oxidize many reduced toxic metals and metalloids, such as $\mathrm{As}(\mathrm{III}), \mathrm{Cr}(\mathrm{III})$, and $\mathrm{Co}(\mathrm{II}),{ }^{20-23}$ as well as organic contaminants. $^{24,25}$ 
Many Mn oxides found in surface environments are poorly crystalline, of biogenic origin and highly reactive. Specifically, $\delta$ $\mathrm{MnO}_{2}$, an amorphous crystalline form of hexagonal birnessite, is quite reactive with respect to $\mathrm{As}(\mathrm{III})$ oxidation. However, during reactions with $\mathrm{As}(\mathrm{III})$, the $\delta-\mathrm{MnO}_{2}$ surface is usually passivated, i.e., the oxidation initially proceeds rapidly followed by a significant decrease in the oxidation rate. ${ }^{20-22}$ The passivation of $\delta-\mathrm{MnO}_{2}$ is primarily caused by the retention of the reaction products, including the sorption of $\mathrm{Mn}$ (II) and $\mathrm{As}(\mathrm{V})$ and the formation of $\mathrm{Mn}$ (III). ${ }^{20,26}$ The sorption of $\mathrm{As}(\mathrm{V})$ and $\mathrm{Mn}$ (II) at the edge sites, which are the location at which As(III) oxidation occurs, can cover the reactive Mn(Iv) sites, thus physically blocking them. ${ }^{21,27}$ In addition, the adsorption of $\mathrm{Mn}$ (II) onto the $\delta-\mathrm{MnO}_{2}$ surface may undergo a cascade of reactions that gradually lead to the formation of less reactive $\mathrm{Mn}$ (III) sites as a result of $\mathrm{Mn}(\mathrm{II}) / \mathrm{Mn}(\mathrm{IV})$ comproportionation. ${ }^{26,28,29}$ Another possible passivation pathway is the formation of $\mathrm{Mn}$ (II) arsenate precipitates on the $\delta-\mathrm{MnO}_{2}$ surface. ${ }^{27}$

The surface passivation of $\delta-\mathrm{MnO}_{2}$ during the oxidation of $\mathrm{Cr}(\mathrm{III})$ and U(Iv) has also been reported in the literature, ${ }^{30,31}$ but the related data for $\mathrm{Sb}$ (III) oxidation are rather limited. The decrease in $\delta-\mathrm{MnO}_{2}$ reactivity when it reacts with $\mathrm{Cr}(\mathrm{III})$ can be attributed to the surface precipitation of $\mathrm{Cr}(\mathrm{OH})_{3}$, which coats the $\delta-\mathrm{MnO}_{2}$ surface, whereas $\mathrm{U}(\mathrm{vI})$ adsorption on the mineral surface can decrease the reactivity of $\delta-\mathrm{MnO}_{2}$ during $\mathrm{U}(\mathrm{Iv})$ oxidation. ${ }^{30,31}$ Although surface passivation has been observed for many toxic metals, such as $\mathrm{As}$ (III) and $\mathrm{Cr}$ (III) (including metalloids), during the oxidation process, to the best of our knowledge, a study that focuses on the mechanisms that control $\mathrm{Sb}$ (III) oxidation by $\delta-\mathrm{MnO}_{2}$ has not been published.

This study aims to investigate the oxidation behavior and mechanisms of $\mathrm{Sb}(\mathrm{III})$ during its reaction with $\delta-\mathrm{MnO}_{2}$. The kinetics of the reaction of $\mathrm{Sb}$ (III) with $\delta-\mathrm{MnO}_{2}$ were examined and compared with those of As(III) using batch kinetic experiments. A combined microscopic and spectroscopic approach, including X-ray photoelectron spectroscopy (XPS), scanning electron microscopy coupled with energy dispersive spectroscopy (SEM-EDS), Fourier transform infrared spectrometry (FTIR), Raman spectroscopy, and X-ray diffraction (XRD), was used to characterize the changes in the $\delta-\mathrm{MnO}_{2}$ mineral composition and the properties involved in the $\mathrm{As}$ (III) and $\mathrm{Sb}$ (III) oxidation process and to identify the newly formed secondary precipitates. In addition, the oxidative mechanism and passivation behavior of $\mathrm{As}(\mathrm{III})$ and $\mathrm{Sb}$ (III) during their respective reactions with $\delta-\mathrm{MnO}_{2}$ were discussed.

\section{Materials and methods}

\subsection{Chemicals and materials}

All chemicals used in this study were of analytical grade or guaranteed grade. Sodium arsenite $\left(\mathrm{NaAsO}_{2}\right)(>98.0 \%)$ and sodium arsenate $\left(\mathrm{Na}_{3} \mathrm{AsO}_{4} \cdot 12 \mathrm{H}_{2} \mathrm{O}\right)(>98.0 \%)$ were obtained from Xiya Reagent Co., Ltd, China. Potassium antimony(III)tartrate hemihydrate $(>99.0 \%)$, antimony pentoxide $(>98.0 \%)$, and potassium pyroantimonate $\left(\mathrm{K}_{2} \mathrm{H}_{2} \mathrm{Sb}_{2} \mathrm{O}_{7} \cdot 4 \mathrm{H}_{2} \mathrm{O}\right)(>98.0 \%)$ were purchased from Sinopharm Chemical Reagent Co., Ltd., China. The stock solutions of $\mathrm{As}(\mathrm{III})$ and $\mathrm{Sb}$ (III) $(10 \mathrm{mM})$ and working solutions of various concentrations were prepared using deionized water.

The $\delta-\mathrm{MnO}_{2}$ used in this study was prepared following the methods described in a previous study. ${ }^{32}$ The properties of $\delta$ $\mathrm{MnO}_{2}$ were analyzed using XRD, SEM-EDS, and a particle size analysis and the detailed results were published in our recent report. $^{24}$

\subsection{Batch kinetic experiments}

Batch experiments to evaluate $\mathrm{As}(\mathrm{III})$ and $\mathrm{Sb}$ (III) oxidation by $\delta$ $\mathrm{MnO}_{2}$ were conducted in $500 \mathrm{~mL}$ Erlenmeyer flasks. A series of $\mathrm{As}(\mathrm{III})$ or $\mathrm{Sb}$ (III) stock solutions was added to $300 \mathrm{~mL}$ of the solution containing $\delta-\mathrm{MnO}_{2}$. The initial $\mathrm{As}(\mathrm{III})$ or $\mathrm{Sb}$ (III) concentrations ranged from 100 to $1000 \mu \mathrm{M}(100,200,500$ and $1000 \mu \mathrm{M})$, and the dosage of $\delta-\mathrm{MnO}_{2}$ was $100 \mathrm{mg} \mathrm{L}^{-1}$. The background electrolyte was $0.01 \mathrm{M} \mathrm{KCl}$, and the $\mathrm{pH}$ of all test solutions during the kinetic experiments was maintained at 5.0 using a $0.1 \mathrm{M}$ acetic acid and sodium acetate buffer system. All reaction flasks for the kinetic experiments were sealed and then shaken using a reciprocating shaker at $200 \mathrm{rpm}$ and $25^{\circ} \mathrm{C}$. At different time intervals $(0,5,10,15,20,25,30,45$ and $60 \mathrm{~min}), 2$ $\mathrm{mL}$ samples of the suspension were collected and filtered through $0.22 \mu \mathrm{m}$ hydrophilic polyvinylidene fluoride membrane filters (Durapore PVDF, Millipore) to quench the oxidation reaction. All filtered samples were stored at $4{ }^{\circ} \mathrm{C}$ in the dark prior to instrumental analysis. The kinetic experiments were performed in triplicate. All glassware used in this study was soaked overnight in $10 \% \mathrm{HNO}_{3}$ and washed thoroughly with deionized water before use.

\subsection{Solid phase analysis}

After the kinetic experiments, the $\delta-\mathrm{MnO}_{2}$ suspensions that were exposed to various $\mathrm{As}(\mathrm{III})$ and $\mathrm{Sb}$ (III) concentrations were centrifuged at $10000 \mathrm{rpm}$ for $10 \mathrm{~min}$. The residual samples were washed three times with deionized water and freeze dried at $-60{ }^{\circ} \mathrm{C}$ for $12 \mathrm{~h}$ in a vacuum freeze dryer (FD-1B-50, Shanghai BiLang Instruments Co., Ltd. China). The freeze-dried samples were further analyzed using XPS, SEM-EDS, XRD, FTIR, and Raman spectroscopy.

SEM images of the original $\delta-\mathrm{MnO}_{2}$ and $\delta-\mathrm{MnO}_{2}$ after reacting with $\mathrm{As}(\mathrm{III})$ or $\mathrm{Sb}$ (III) were recorded using a Zeiss Super 55 VP SEM coupled with a Bruker XFlash 5010 EDS system. The samples were fixed onto the SEM stage prior to SEM-EDS analysis using double-sided adhesive carbon tape. A thin gold coating $(<5 \mathrm{~nm})$ was sputtered onto the carbon to prevent surface charging during the SEM analyses. The SEM images were acquired at magnifications ranging from $1000 \times$ to $100000 \times$ with an accelerating voltage of $20 \mathrm{kV}$. The coated samples were also examined using the EDS system to obtain a rapid semi-quantitative elemental analysis. The EDS spectra were measured obtained at selected areas of the particles with a counting time of $60 \mathrm{~s}$. The detection limit was approximately $0.1 \%$ (wt) for most elements and the relative percentage content of the elements was normalized. The amorphous state and any crystalline phases of $\delta-\mathrm{MnO}_{2}$ before and after reacting with As(III) or $\mathrm{Sb}(\mathrm{III})$ were determined using an X-ray diffractometer 
(Bruker D8 advance, Germany). Approximately $100 \mathrm{mg}$ of the sample was ground into a fine powder prior to the XRD measurements. The XRD spectra were recorded using a $\mathrm{Cu} \mathrm{K} \alpha$ radiation source with an accelerating voltage of $40 \mathrm{kV}$ and an electron-generating current of $30 \mathrm{~mA}$. The diffraction angles were scanned from 10 to $80^{\circ}(2 \theta)$ at $0.05^{\circ}(2 \theta)$ per step. The possible crystalline phases and secondary products were identified according to the standard patterns published by the International Center for Diffraction Data.

To determine the various functional structures of $\delta-\mathrm{MnO}_{2}$ involved in the $\mathrm{As}$ (III) or $\mathrm{Sb}$ (III) oxidation process, the samples were analyzed comparatively with the FTIR spectra. The spectra were recorded using a Thermo Nicolet Nexus 5700 spectrophotometer in the range of $4000-400 \mathrm{~cm}^{-1}$ with a resolution of $2 \mathrm{~cm}^{-1}$. Prior to the FTIR analysis, the freeze-dried samples were mixed and ground with spectrum-pure potassium bromide at a mass of $1 \%$ and then compressed into pellets. The spectrum of the pure potassium bromide was subtracted from each experimental spectrum to correct for the background. In addition, the pristine and reacted $\delta-\mathrm{MnO}_{2}$ samples were further examined using a Renishaw microprobe RM2000 confocal Raman microscope equipped with $10 \times$ and $50 \times$ objectives. Raman spectra were collected at wavenumbers ranging from 50 to $4000 \mathrm{~cm}^{-1}$ at a nominal resolution of $1 \mathrm{~cm}^{-1}$ using a $532 \mathrm{~nm}$ laser for excitation. The samples were analyzed through a $50 \times$ microscope objective lens, and the acquisition time was set to $300 \mathrm{~s}$ with 2-4 accumulations. The sampling depths were 1.5$2.0 \mu \mathrm{m}$. A low laser power $(1 \mathrm{~mW})$ was selected to avoid mineral transformations and radiation damage during the Raman measurements. At least three independent measurements were carried out and the results did not exhibit significant differences.

XPS was used to quantify the surface element composition on the $\delta-\mathrm{MnO}_{2}$ surface before and after reacting with $\mathrm{Sb}$ (III) and As(III). Prior to the XPS measurements, approximately $50 \mathrm{mg}$ of each powder sample was adhered to the surface of double-sided adhesive tape and placed under vacuum. A Thermo Fisher Scientific ESCALAB 250Xi X-ray photoelectron spectrometer with a monochromatized $\mathrm{Al} \mathrm{K} \alpha$ radiation source $(1486.6 \mathrm{eV})$ at $200 \mathrm{~W}$ under a residual pressure of $1 \times 10^{-9}$ mbar was used to record the data. A survey scan was collected using binding energies ranging from 0 to $1200 \mathrm{eV}$ with a dwell time of $100 \mathrm{~ms}$ and a pass energy of $150 \mathrm{eV}$ at a step of $1 \mathrm{eV}$ per sweep. Highresolution spectra for As 3d, Sb 3d, Mn 3s, Mn 3p, Mn 2p and $\mathrm{O} 1 \mathrm{~s}$ were obtained using a $20 \mathrm{eV}$ pass energy at a step of $0.1 \mathrm{eV}$, and the dwell time was increased to $250 \mathrm{~ms}$. To compensate for the charging effects, the spectra were calibrated $\mathrm{C} 1 \mathrm{~s}$ as the conducting reference at a fixed value of $284.6 \mathrm{eV}$.

Curve fitting, data analysis and the quantification of the Mn $3 \mathrm{p}$ and $\mathrm{O}$ 1s high-resolution XPS spectra were performed using CasaXPS software (V2.3.17PR1.1). The spectra were well fitted using non-linear Shirley-type background subtraction with Flattened Lorentzian (FL) function to determine the optimal spectral baseline and peaks. The oxidation state of Mn was identified by analyses of the Mn 3s multiplet splitting and the position and shape of the Mn 3p regions. For determining the binding energy of the samples in the Mn $3 p$ region, gold ( $\mathrm{Au}$ ) was vacuum-deposited on the Mn standards to charge reference the binding energy with respect to the $\mathrm{Au} 4 \mathrm{f}_{7 / 2}$ peak position $(84.0 \mathrm{eV})$. After non-linear Shirley-type background subtraction, the data were normalized by comparison with $\mathrm{Mn}$ (II), Mn(III) and Mn(Iv) reference standards. For each sample, a direction set method was conducted to adjust every fitting parameter (FWHM, the full width at half maximum; $H$, the peak height; $E$, the peak position center) and minimize the value of residual standard deviation (STD). The peak position and relevant parameters from curve fitting of $\mathrm{Mn} \mathrm{3s,} \mathrm{Mn} \mathrm{3p} \mathrm{and} \mathrm{O}$ 1s high resolution spectra are listed in Tables $\mathrm{S} 1-\mathrm{S} 3 . \dagger$

The zeta potentials and particle sizes of the fresh $\delta-\mathrm{MnO}_{2}$ were determined using a Malvern Zetasizer Nano analyzer (Malvern, UK). The BET surface of $\delta-\mathrm{MnO}_{2}$ was examined using an ASAP 2010 specific surface area and porosity analyzer (Micromeritics, USA).

\subsection{Determination of $\mathrm{As}, \mathrm{Sb}$ and $\mathrm{Mn}$ (II) in solution}

The concentrations of $\mathrm{As}(\mathrm{III} / \mathrm{V})$ and $\mathrm{Sb}(\mathrm{III} / \mathrm{V})$ in solution were determined using liquid chromatography combined with an AFS 830 hydride generation atomic florescence spectroscope (LC-HG-AFS) (Beijing Jitian, China). The inorganic As and Sb species were separated using a Hamilton PRP-X100 anion exchange column $(250 \mathrm{~mm} \times 4.1 \mathrm{~mm}, 10 \mu \mathrm{m})$ with a flow rate of

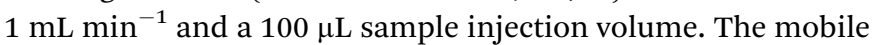
phases for the $\mathrm{As}(\mathrm{III}) / \mathrm{As}(\mathrm{v})$ and $\mathrm{Sb}(\mathrm{III}) / \mathrm{Sb}(\mathrm{v})$ separation were $15 \mathrm{mM}\left(\mathrm{NH}_{4}\right)_{2} \mathrm{HPO}_{4}$ (pH adjusted to 6.0 using $10 \%$ formic acid) and $1 \mathrm{mM}$ potassium hydrogen phthalate with $10 \mathrm{mM}$ EDTA$2 \mathrm{Na}$, respectively. The retention times of the As(III) and As(V) species were $2.54 \mathrm{~min}$ and $10.16 \mathrm{~min}$, respectively, while those of $\mathrm{Sb}$ (III) and $\mathrm{Sb}(\mathrm{v})$ were $4.03 \mathrm{~min}$ and $2.63 \mathrm{~min}$, respectively. The concentrations for the standard curves of $\mathrm{As}$ and $\mathrm{Sb}$ ranged from 10 to $100 \mu \mathrm{g} \mathrm{L}^{-1}$. The current-carrying and reducing agents used were $5 \% \mathrm{HNO}_{3}(\mathrm{v} / \mathrm{v})$ and $2 \% \mathrm{KBH}_{4}(\mathrm{~m} / \mathrm{v}$ ) (prepared in $0.5 \%$ $\mathrm{KOH})$, respectively. The recovery rates from the $\mathrm{Sb}(\mathrm{III}), \mathrm{Sb}(\mathrm{v})$, As(III) and As(v) analyses using the LC-HG-AFS system were $97.5 \%, 99.1 \%, 102.4 \%$ and $99.5 \%$, respectively. The amounts of As or $\mathrm{Sb}$ in the solid during the oxidation process were determined by calculating the difference between the initial concentrations of $\mathrm{As}(\mathrm{III})$ or $\mathrm{Sb}(\mathrm{III})$ and the residual concentrations of $\mathrm{As}$ or $\mathrm{Sb}$ in solution with the reaction time. The $\mathrm{Mn}$ (II) concentration in solution was determined using manganese formaldehyde oxime spectrophotometry. ${ }^{33}$

\section{Results and discussion}

\subsection{Kinetics of $\mathrm{As}(\mathrm{III})$ and $\mathrm{Sb}$ (III) oxidation by $\delta-\mathrm{MnO}_{2}$}

The kinetic experiments in this study were performed by reacting 100, 200, 500 and $1000 \mu \mathrm{M} \mathrm{As}(\mathrm{III})$ or $\mathrm{Sb}(\mathrm{III})$ with $100 \mathrm{mg}$ $\mathrm{L}^{-1} \delta-\mathrm{MnO}_{2}$ at $\mathrm{pH} 5.0$ (Fig. 1). The residual As(III) concentrations in solution decreased as a function of the reaction time, and the As(III) oxidation rate decreased with the increasing initial As(III) concentrations. The reaction process for $\mathrm{Sb}$ (III) oxidation showed a similar pattern. However, the oxidation rate of $\mathrm{Sb}(\mathrm{III})$ was more rapid than that of $\mathrm{As}(\mathrm{III})$. 

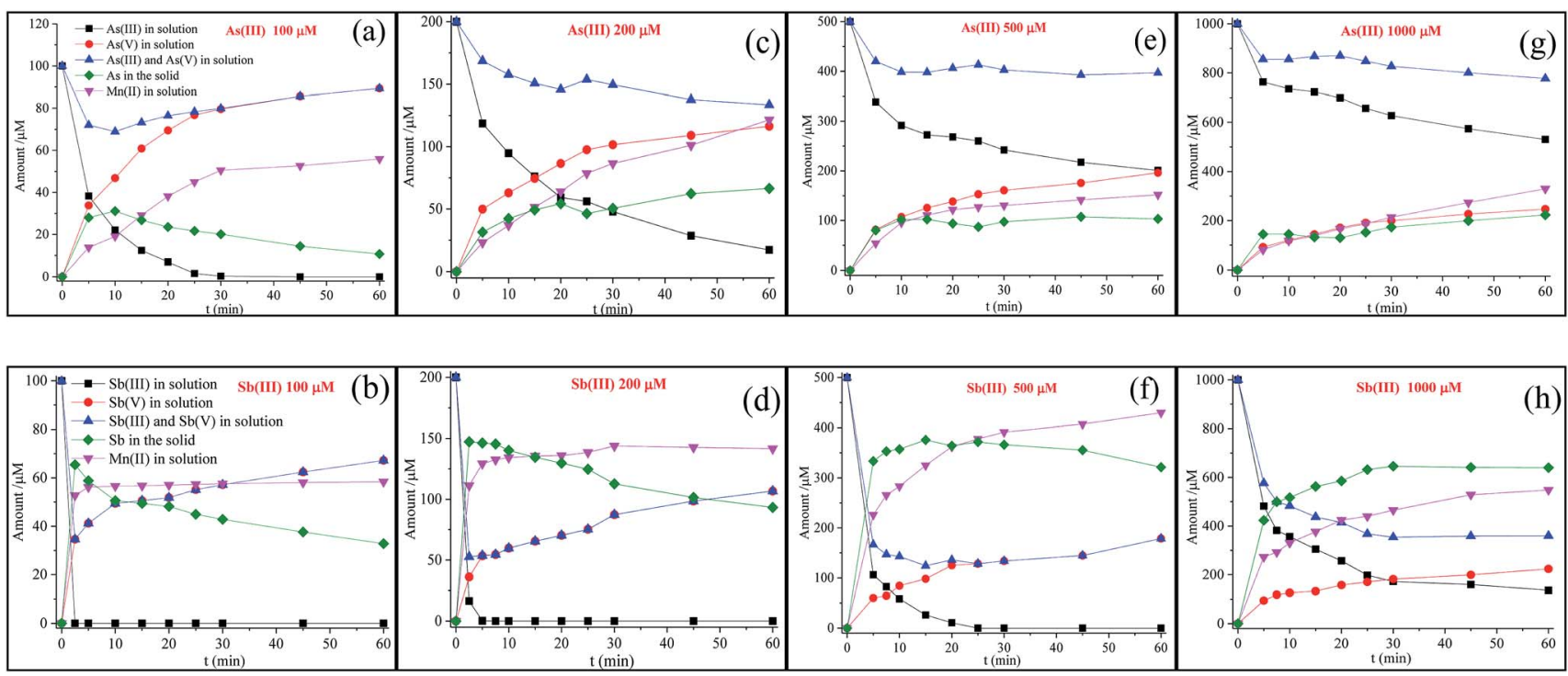

Fig. 1 Changes in As and Sb species and the releasing of $\mathrm{Mn}(I)$ in the solution versus reaction time, where 100, 200, 500, and 1000 $\mu \mathrm{M} \mathrm{As(II)} \mathrm{or}$ $\mathrm{Sb}(\mathrm{III})$ reacted with $100 \mathrm{mg} \mathrm{L}^{-1} \delta-\mathrm{MnO}_{2}$ at $\mathrm{pH}$ 5.0.

The first-order rate equation is frequently used to describe the depletion of $\mathrm{As}(\mathrm{III})$ by $\delta-\mathrm{MnO}_{2}$ (eqn (1) and (2)). ${ }^{\mathbf{2 4 , 2 7}}$

$$
\begin{gathered}
\ln \left(C_{t} / C_{0}\right)=-k_{\mathrm{obs}} t \\
t_{1 / 2}=\ln 2 / k_{\mathrm{obs}}
\end{gathered}
$$

where $k_{\mathrm{obs}}\left(\mathrm{min}^{-1}\right)$ is the rate constant of the first-order model, $C_{t}$ is the concentration of $\mathrm{As}$ (III) or $\mathrm{Sb}$ (III) remaining in solution at time $t, C_{0}$ is the initial concentration of $\mathrm{As}(\mathrm{III})$ or $\mathrm{Sb}$ (III), and $t_{1 / 2}$ represents the time required when the $\mathrm{As}(\mathrm{III})$ or $\mathrm{Sb}$ (III) concentration is decreased to half of its initial value.

The kinetics data were generally well fitted for As(III) $\left(R^{2}=0.930-0.993\right)$ and $\mathrm{Sb}(\mathrm{III})\left(R^{2}=0.870-0.996\right)$ after oxidation by $\delta-\mathrm{MnO}_{2}$ (Table 1 ). The $k_{\mathrm{obs}}$ values for the $\mathrm{Sb}(\mathrm{III})$ concentrations from 100 to $1000 \mu \mathrm{M}$ were $6.14-44.71$ times higher than those for As(III). In contrast, the half-life values for $\mathrm{Sb}$ (III) oxidation were only $2.20-15.97 \%$ of those of As(III). The disparities in the oxidation rates between $\mathrm{Sb}$ (III) and As(III) were possibly due to the significant surface passivation of $\delta-\mathrm{MnO}_{2}$ during $\mathrm{As}(\mathrm{III})$ oxidation. During the oxidation process of $\mathrm{As}(\mathrm{III}), \mathrm{As}(\mathrm{v})$ and $\mathrm{Mn}$ (II) were produced according to the following reaction (eqn (3)).

Table 1 Rate constants $k_{\text {obs }}$ and $t_{1 / 2}$ for $\mathrm{As}(\mathrm{III})$ and $\mathrm{Sb}(\mathrm{II})$ by $\delta-\mathrm{MnO}_{2}$

\begin{tabular}{lllrl}
\hline Items & Con. $(\mu \mathrm{M})$ & $k_{\text {obs }}$ & $t_{1 / 2}(\mathrm{~min})$ & $R^{2}$ \\
\hline \multirow{2}{*}{$\operatorname{As}($ III) } & 100 & 0.188 & 3.68 & 0.930 \\
& 200 & 0.034 & 20.32 & 0.993 \\
& 500 & 0.009 & 80.58 & 0.932 \\
& 1000 & 0.007 & 100.43 & 0.987 \\
$\mathrm{Sb}$ (III) & 100 & 2.923 & 0.23 & 0.996 \\
& 200 & 1.520 & 0.45 & 0.870 \\
& 500 & 0.145 & 4.79 & 0.982 \\
& 1000 & 0.043 & 16.04 & 0.962
\end{tabular}

$$
\begin{aligned}
\mathrm{MnO}_{2(\mathrm{~s})}+\mathrm{H}_{3} \mathrm{AsO}_{3(\mathrm{aq})}+\mathrm{H}_{(\mathrm{aq})}^{+} \rightarrow \\
\mathrm{Mn}_{(\mathrm{aq})}{ }^{++}+\mathrm{H}_{2} \mathrm{AsO}_{4(\mathrm{aq})}{ }^{-}+\mathrm{H}_{2} \mathrm{O}_{(\mathrm{aq})}
\end{aligned}
$$

As shown in Fig. 1, at a low As(III) concentration $(100 \mu \mathrm{M})$, the release of $\operatorname{As}(\mathrm{v})$ into the solution increased with the reaction time, and the concentrations of As(v) were significantly higher than those of Mn(II) in solution. This observation was attributed to the $\mathrm{Mn}$ (II) adsorption at the reactive sites, leading to the inhibition of $\mathrm{As}(\mathrm{v})$ adsorption. ${ }^{21}$ With the increasing initial As(III) concentration, the difference between the As(v) and Mn(II) concentrations diminished and eventually disappeared at a high $\mathrm{As}(\mathrm{III})$ concentration $(1000 \mu \mathrm{M})$. These results suggest that once the $\delta-\mathrm{MnO}_{2}$ reactive sites were completely occupied, freshly formed $\mathrm{Mn}$ (II) and As(v) tended to fully release into the solution at a mole ratio of $1: 1$. In addition, a slow oxidation rate was observed for $\delta-\mathrm{MnO}_{2}$ with a high concentration of As(III). This result is consistent with the study reported by Lafferty et al. (2010a); in their study, during the As(III) reaction process, the oxidation rate significantly decreased but still continued in the $\mathrm{Mn}(\mathrm{II})$-saturated $\delta-\mathrm{MnO}_{2}$ system. ${ }^{26}$

As(III) must adsorb onto mineral surfaces prior to oxidation, but a number of studies have indicated that only As(v) can be retained at the reactive sites of $\delta-\mathrm{MnO}_{2} \cdot{ }^{20,21,26}$ In the highresolution XPS spectra (Text S1-S9, Fig. 2 and S1 and Table $\mathrm{S} 4 \dagger)$, the peaks correlated with the binding energies at $45.4 \pm$ $0.1 \mathrm{eV}$ and $540.4 \pm 0.2 \mathrm{eV}$ were assigned to $\mathrm{As} 3 \mathrm{~d}$ and $\mathrm{Sb} 3 \mathrm{~d}_{3 / 2}$, respectively, which indicated that only $\mathrm{As}(\mathrm{v})$ and $\mathrm{Sb}(\mathrm{v})$ were present on the surface of $\delta-\mathrm{MnO}_{2} \cdot{ }^{34,35}$

The $\delta-\mathrm{MnO}_{2}$ has two types of reactive sites: vacant sites within the Mn(Iv) octahedral layers and edge sites at the Mn(Iv) octahedral layer edges. ${ }^{36,37}$ As(III) oxidation and As(v) adsorption occur primarily at the edge sites, while $\mathrm{Mn}$ (II) tends to adsorb strongly at both the vacant and edge sites of $\delta-\mathrm{MnO}_{2}{ }^{27,38}$ The surface passivation of $\delta-\mathrm{MnO}_{2}$ was primarily caused by the 

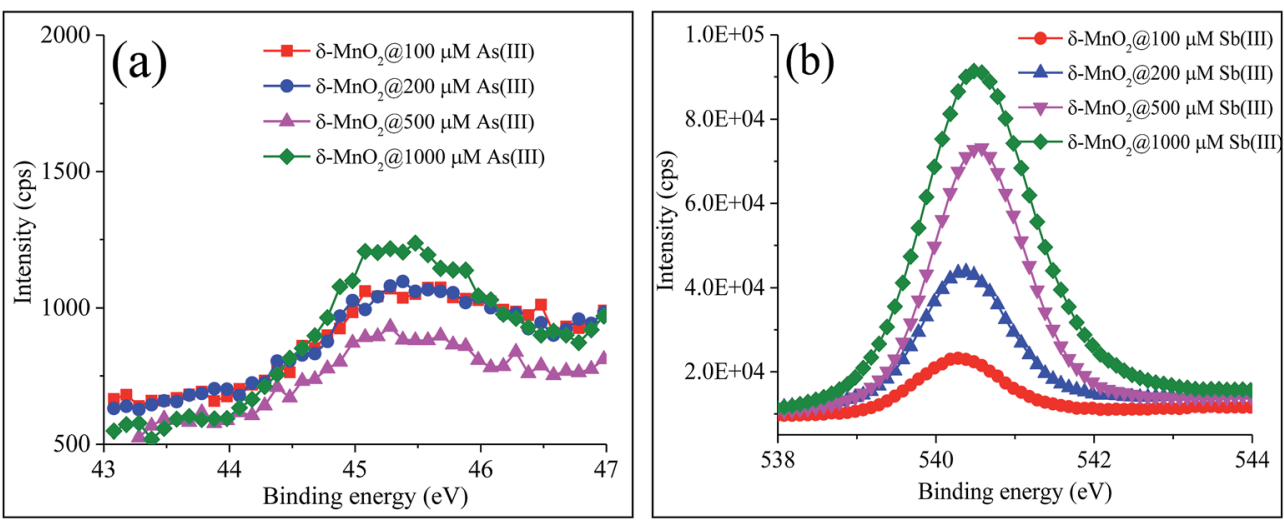

Fig. 2 High-resolution XPS spectra of (a) As $3 d$ and (b) Sb $3 d_{3 / 2}$.

retention of secondary products such as $\mathrm{Mn}$ (II) on the $\delta-\mathrm{MnO}_{2}$ reactive sites. ${ }^{26,39}$ The vacant sites were preferentially occupied by Mn(II) until all sites were occupied, and then, Mn(II) was expected to compete with As(v) for the edge sites. Previous studies have also indicated that $\mathrm{Mn}$ (II) adsorption on the $\delta-\mathrm{MnO}_{2}$ surface is crucial for initiating passivation during the early stages of the reaction with $\mathrm{As}(\mathrm{III}) .^{21,26}$

For poorly crystallized $\delta-\mathrm{MnO}_{2}$, the edge sites hold a relatively high proportion of the total particle charge, and thus, similar to $\mathrm{As}(\mathrm{III})$, the particle edge sites of $\delta-\mathrm{MnO}_{2}$ may contribute significantly to $\mathrm{Sb}$ (III) adsorption prior to $\mathrm{Sb}$ (III) oxidation..$^{20,27,40,41}$ After $\mathrm{Sb}$ (III) reacted with $\delta$ - $\mathrm{MnO}_{2}$ (Fig. 1), the release of $\mathrm{Sb}(\mathrm{v})$ and $\mathrm{Mn}$ (II) was quite different from that of the As(III) reaction. Although the oxidation rate of $\mathrm{Sb}$ (III) was faster than that of As(III), significantly less $\mathrm{Sb}(\mathrm{v})$ was released into the solution than $\mathrm{As}(\mathrm{V})$. The liberated $\mathrm{Mn}(\mathrm{II})$ rapidly achieved equilibrium (i.e., in less than $10 \mathrm{~min}$ ) at low $\mathrm{Sb}$ (III) concentrations $(100 \mu \mathrm{M}$ and $200 \mu \mathrm{M}$ ), whereas the $\mathrm{Mn}$ (II) concentration increased continuously during the As(III) oxidation process. In addition, during the $\mathrm{Sb}$ (III) reaction with $\delta$ - $\mathrm{MnO}_{2}$, the $\mathrm{Mn}$ (II) concentrations in solution were clearly higher than those from As(III) oxidation. These results suggest that the mechanisms of the $\mathrm{Sb}$ (III) reaction with $\delta-\mathrm{MnO}_{2}$ might be completely different from those of As(III) oxidation.

In addition, as shown in Fig. 1(a), at low As(III) concentrations, the adsorption of $\mathrm{As}(\mathrm{v})$ onto the solid quickly increased within $10 \mathrm{~min}$, followed by a continuous decrease in $\mathrm{As}(\mathrm{v})$ adsorption until the end of the experiments. The decrease in the As(v) adsorption on the solid was attributed to the competition between $\operatorname{As}(\mathrm{v})$ and $\mathrm{Mn}$ (II) for the reactive sites. The changes in $\mathrm{Sb}(\mathrm{v})$ in the solid also exhibited a similar tendency with the $\mathrm{Sb}$ (III) concentrations of 100 and $200 \mu \mathrm{M}$ (Fig. 1(b) and (d)). At high $\mathrm{As}(\mathrm{III})$ or $\mathrm{Sb}(\mathrm{III})$ concentrations (Fig. 1(e)-(h)), $\mathrm{As}(\mathrm{v})$ or $\mathrm{Sb}(\mathrm{v})$ in the solid slightly increased with the reaction time. $\mathrm{The} \mathrm{Sb}(\mathrm{v})$ content in the solid increased more significantly than the As content (Fig. 2).

\subsection{Mn oxidation state analysis}

To better understand the mechanisms of the $\mathrm{Sb}$ (III) and $\mathrm{As}$ (III) reactions with $\delta-\mathrm{MnO}_{2}$, the changes in the $\mathrm{Mn}$ oxidation states were investigated. The magnitude of the Mn 3s XPS multiplet splitting was used to determine changes in the $\delta-\mathrm{MnO}_{2}$ oxidation state during the $\mathrm{As}(\mathrm{III})$ and $\mathrm{Sb}$ (III) reactions (Fig. S2 and S3 and Table $55 \dagger$ ). The pristine $\delta-\mathrm{MnO}_{2}$ sample showed multiplet splitting at $4.86 \mathrm{eV}$. According to the linear correlation between the Mn 3s multiplet splitting and the average oxidation state of $\mathrm{Mn}$ (Fig. S3 $\dagger$ ), the $\mathrm{Mn}$ in $\delta$ - $\mathrm{MnO}_{2}$ exhibited an average oxidation state at $3.56 \mathrm{eV}$, indicating the presence of $\mathrm{Mn}$ (III) and $\mathrm{Mn}$ (II) impurities. ${ }^{42,43}$ After reacting with As(III), the values for the Mn $3 \mathrm{~s}$ multiplet splitting increased slightly with the increasing initial As(III) concentrations. The average Mn oxidation states ranged from 3.36 to 3.13 , which coincided with the decrease in the Mn oxidation state from $\mathrm{Mn}$ (Iv) to $\mathrm{Mn}(\mathrm{III} / \mathrm{Iv})$. The oxidation of $1000 \mu \mathrm{M} \mathrm{Sb}$ (III) by $\delta-\mathrm{MnO}_{2}$ led to a more significant increase in the multiplet splitting from 4.86 to 5.82 than that observed in the $\mathrm{As}(\mathrm{III})$ reaction, indicating the rapid reduction of $\mathrm{Mn}$ (IV) to $\mathrm{Mn}(\mathrm{II})$.

The changes in the relative content of Mn(Iv, III and II) in the pristine and reacted $\delta-\mathrm{MnO}_{2}$ were quantified by conducting a high-resolution XPS spectral analysis of the Mn 3p level (Fig. S4 $\uparrow$ and Table 2). The percent contents of Mn(Iv), Mn(III) and $\mathrm{Mn}$ (II) in the pristine $\delta-\mathrm{MnO}_{2}$ were $57.6 \%, 28.43 \%$ and $13.97 \%$, respectively. After reacting with As(III) or Sb(III), the Mn $3 p$ high-resolution spectra shifted toward a lower binding energy, indicating a decrease in the percentage of $\mathrm{Mn}$ (Iv) on the $\delta$ - $\mathrm{MnO}_{2}$ surface. During the reaction of $\delta-\mathrm{MnO}_{2}$ with various

Table 2 Percentage of $M n 3 p$ spectra by fitting $M n(I v), M n(I I)$ and $M n(॥)$ reference spectra

\begin{tabular}{|c|c|c|c|c|}
\hline Items & Con. $(\mu \mathrm{M})$ & Mn(Iv) (\%) & $\begin{array}{l}\operatorname{Mn}(\mathrm{III}) \\
(\%)\end{array}$ & $\operatorname{Mn}(\mathrm{II})(\%)$ \\
\hline$\delta-\mathrm{MnO}_{2}$ & 0 & 57.6 & 28.43 & 13.97 \\
\hline \multirow[t]{4}{*}{$\delta-\mathrm{MnO}_{2} @ \mathrm{As}(\mathrm{III})$} & 100 & 47.03 & 32.68 & 20.29 \\
\hline & 200 & 42.83 & 35.01 & 22.16 \\
\hline & 500 & 34.29 & 37.54 & 28.17 \\
\hline & 1000 & 32.03 & 39.35 & 28.64 \\
\hline \multirow{4}{*}{ 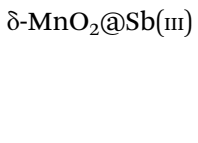 } & 100 & 42.15 & 34.65 & 23.20 \\
\hline & 200 & 41.76 & 33.25 & 24.99 \\
\hline & 500 & 28.00 & 32.18 & 39.82 \\
\hline & 1000 & 8.60 & 20.48 & 69.92 \\
\hline
\end{tabular}


As(III) decrease in the percentage of, the relative content of $\mathrm{Mn}$ (III) and $\mathrm{Mn}$ (II) increased, while that of $\mathrm{Mn}$ (IV) decreased. These data were consistent with the average oxidation determined from fitting the Mn 3s multiplet splitting data. The increased concentration of $\mathrm{Mn}(\mathrm{II})$ on the $\delta-\mathrm{MnO}_{2}$ surface was one of the major causes of early $\delta-\mathrm{MnO}_{2}$ passivation. In addition, the formation of less reactive $\mathrm{Mn}(\mathrm{III})$ sites during the comproportionation reaction of the adsorbed $\mathrm{Mn}$ (II) with the original $\mathrm{Mn}$ (Iv) was also a primary reason for the passivation of $\delta-\mathrm{MnO}_{2}$. These results were consistent with those from previous reports, suggesting that the adsorption of $\mathrm{Mn}$ (II) and $\mathrm{Mn}$ (III) on the $\delta-\mathrm{MnO}_{2}$ surface passivates $\delta-\mathrm{MnO}_{2}$ and simultaneously decreases the As(III) oxidation rate. ${ }^{\mathbf{2 1 , 2 6}}$

After reacting with $\mathrm{Sb}(\mathrm{III})$, a more significant decrease in the Mn(IV) percentage and an increase in the Mn(II) percentage was observed with the increasing initial $\mathrm{Sb}$ (III) concentration (Table 2). The percentage of $\mathrm{Mn}$ (Iv) dropped to $8.60 \%$, while that of $\mathrm{Mn}$ (II) reached $69.92 \%$ after reacting with $1000 \mu \mathrm{M} \mathrm{Sb}(\mathrm{III})$. More importantly, the $\mathrm{Mn}$ (III) and $\mathrm{Mn}(\mathrm{IV})$ content in $\delta-\mathrm{MnO}_{2}$ proportionally decreased together with the increasing initial $\mathrm{Sb}$ (III) concentration. This trend was entirely different from that observed during the As(III) oxidation. The surface passivation of $\delta-\mathrm{MnO}_{2}$ appeared to be the rate-limiting step for the As(III) oxidation, but it may not have been the limiting factor for controlling $\mathrm{Sb}$ (III) oxidation. Additional $\mathrm{O}$ 1s high-resolution spectra were collected to better understand the oxygen binding characteristics of $\delta-\mathrm{MnO}_{2}$ during $\mathrm{As}(\mathrm{III})$ and $\mathrm{Sb}$ (III) oxidation.

The $\mathrm{O}$ 1s high-resolution spectra were divided into three peaks located at 530.0, 531.4 and $532.4 \mathrm{eV}$, which corresponded to lattice oxygen $\left(\mathrm{O}_{\text {latt }}\right)$, surface-absorbed oxygen $\left(\mathrm{O}_{\text {ads }}\right)$ and chemisorbed oxygen species $\left(\mathrm{O}_{\mathrm{H}_{2} \mathrm{O}}\right)$, respectively ${ }^{\mathbf{4 4}}$ (Fig. 3 and Table $\mathrm{S} 6 \dagger)$. The predominant source of $\mathrm{O}_{\text {latt }}$ originated from the $\delta-\mathrm{MnO}_{2}$ itself, and it changed during the oxidation process. $\mathrm{O}_{\text {ads }}$ was primarily derived from $\mathrm{As}$ (III) and $\mathrm{Sb}$ (III) and thus existed as an experimental condition. After the reactions with $\mathrm{Sb}$ (III) and As(III), the percentage of $\mathrm{O}_{\text {latt }}$ significantly decreased along with the increasing percentage of $\mathrm{O}_{\text {ads }}$, indicating that the reactions of $\mathrm{Sb}$ (III) and $\mathrm{As}(\mathrm{III})$ with $\delta-\mathrm{MnO}_{2}$ led to changes in the $\delta-\mathrm{MnO}_{2}$ structure. The higher values of $\mathrm{O}_{\text {ads }} / \mathrm{O}_{\text {latt }}$ after $\mathrm{Sb}$ (III) oxidation than those obtained after As(III) oxidation were primarily attributed to the fact that more $\mathrm{Sb}(\mathrm{v})$ was retained on the $\delta$ $\mathrm{MnO}_{2}$ surface. The percentage of $\mathrm{O}_{\mathrm{H}_{2} \mathrm{O}}$ in the $\delta-\mathrm{MnO}_{2}$ changed slightly during the reactions with $\mathrm{Sb}$ (III) and $\mathrm{As}(\mathrm{III})$, indicating that the adsorbed $\mathrm{H}_{2} \mathrm{O}$ did not participate in the reaction between $\delta-\mathrm{MnO}_{2}$ and $\mathrm{Sb}(\mathrm{III})$ or $\mathrm{As}(\mathrm{III}) .^{45}$

\section{3 $\delta-\mathrm{MnO}_{2}$ property analysis}

The changes in the properties of $\delta-\mathrm{MnO}_{2}$ before and after the $\mathrm{As}(\mathrm{III})$ and $\mathrm{Sb}$ (III) oxidation were investigated using FTIR, Raman spectroscopy, SEM-EDS and XRD. The results are shown in Fig. 4 and 5.

FTIR and Raman spectra analyses were used to identify the functional groups of $\delta-\mathrm{MnO}_{2}$ involved in the reactions with $\mathrm{As}(\mathrm{III})$ and $\mathrm{Sb}$ (III). As shown in Fig. 4a, several of the typical absorption bands for pristine $\delta-\mathrm{MnO}_{2}$ that were observed in the

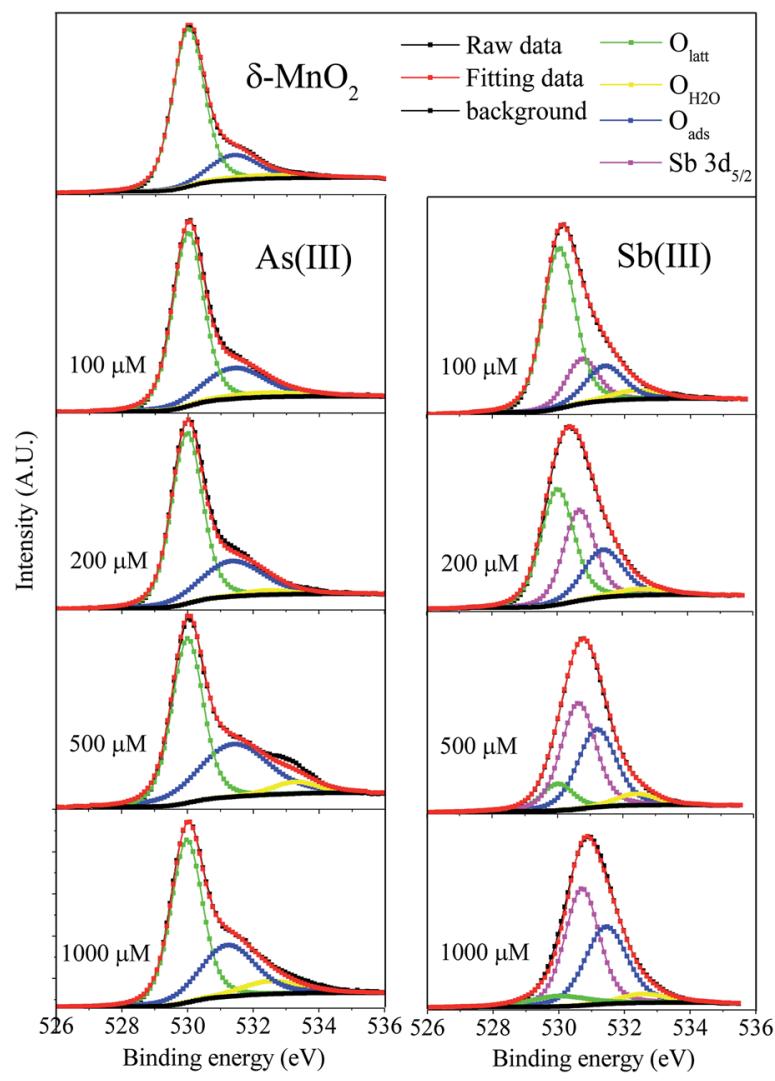

Fig. 3 Fitting of $\mathrm{O} 1 \mathrm{~s}$ XPS high resolution spectra for $\delta-\mathrm{MnO}_{2}$ before and after reaction with $\mathrm{As}(\mathrm{III})$ and $\mathrm{Sb}(\mathrm{III})$. $\mathrm{O}_{\text {latt }}$ (surface lattice oxygen), $\mathrm{O}_{\mathrm{H}_{2} \mathrm{O}}$ (chemisorbed oxygen species) and $\mathrm{O}_{\text {ads }}$ (surface absorb oxygen).

absorption band at $1624 \mathrm{~cm}^{-1}$ were ascribed to the hydroxyl $(-\mathrm{OH})$ groups of the physically adsorbed water molecules, ${ }^{\mathbf{4 6}}$ and two broad features at 520 and $460 \mathrm{~cm}^{-1}$ were assigned to the Mn-O lattice vibration of the Mn oxides. ${ }^{47}$ The changes in the bond positions of $\delta-\mathrm{MnO}_{2}$ in the FTIR spectra were insignificant during its reaction with various concentrations of As(III) (Fig. 4a). After the reactions between $\delta-\mathrm{MnO}_{2}$ and $\mathrm{Sb}(\mathrm{III})$, significant changes in the FTIR spectra were observed (Fig. 4b). The Mn-O located in the "fingerprint zone" disappeared in the presence of high concentrations of $\mathrm{Sb}(\mathrm{III})(500$ and $1000 \mu \mathrm{M})$. A new peak near $1060 \mathrm{~cm}^{-1}$ appeared, and the relative adsorption intensity increased with the $\mathrm{Sb}(\mathrm{III})$ concentration, which was ascribed to the formation of the $\mathrm{Sb}-\mathrm{O}$ band (Fig. $4 \mathrm{~b}$ and $\mathrm{S} 5 \dagger$ ). The spectral results indicate that remarkable changes to $\delta$ $\mathrm{MnO}_{2}$ occurred during the reaction with $\mathrm{Sb}$ (III), whereas the $\delta$ $\mathrm{MnO}_{2}$ structure was not significantly affected during the As(III) oxidation process.

Fig. 4c and d shows the Raman spectra of $\delta-\mathrm{MnO}_{2}$ before and after reacting with $\mathrm{As}(\mathrm{III})$ and $\mathrm{Sb}$ (III). For the pristine $\delta-\mathrm{MnO}_{2}$, the sharp peak near $640 \mathrm{~cm}^{-1}$ was assigned to the characteristic peak of the $\mathrm{Mn}$ oxides. ${ }^{\mathbf{4 8}, 49}$ Significant changes were not observed in $\delta-\mathrm{MnO}_{2}$ during its reaction with $1000 \mu \mathrm{M}$ As(III) (Fig. 4c), whereas the Raman spectra clearly changed after $\mathrm{Sb}$ (III) reacted with $\delta-\mathrm{MnO}_{2}$ (Fig. 4d). The characteristic peak of the $\mathrm{Mn}$ oxides widened and became more intense, and a new peak located near $470 \mathrm{~cm}^{-1}$ appeared. 

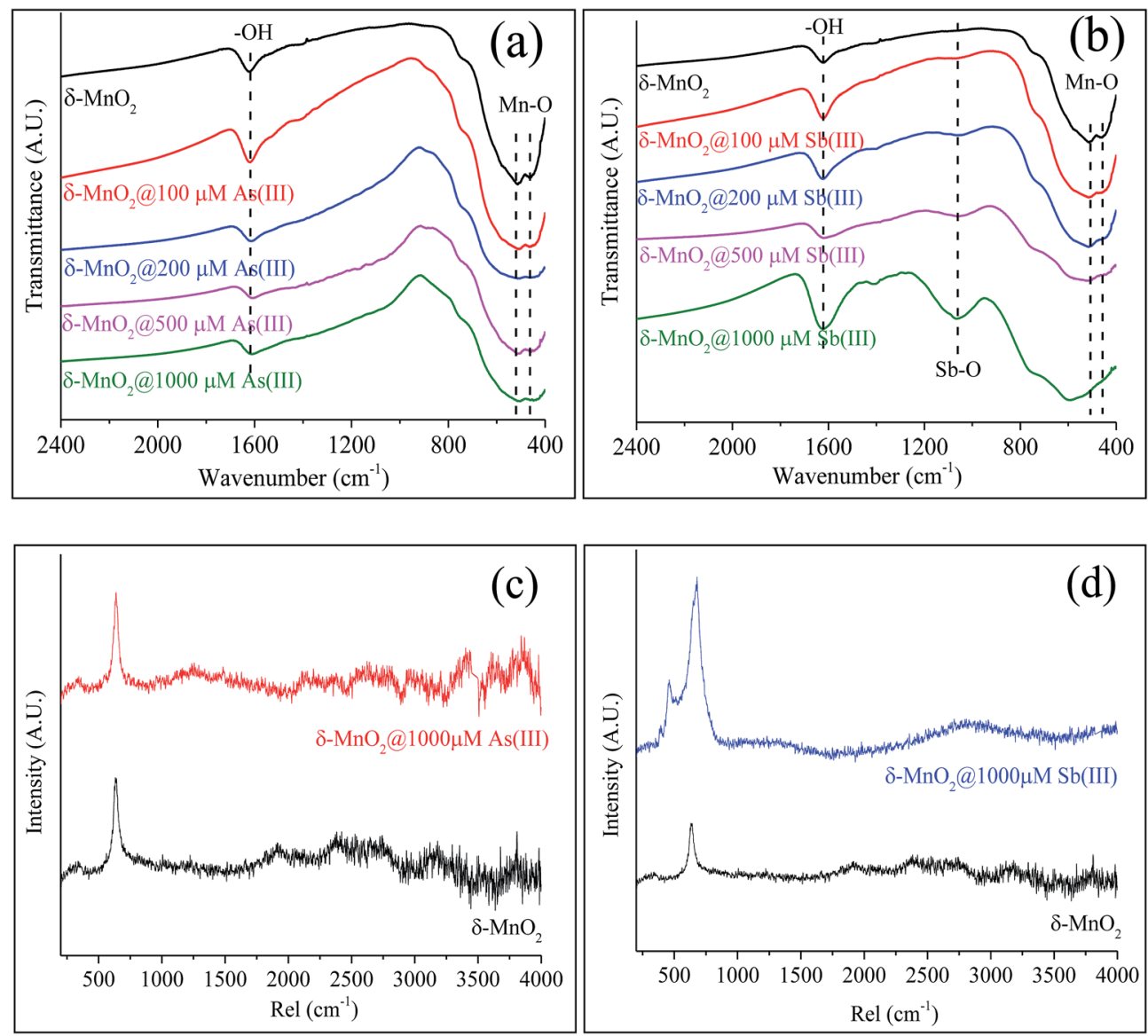

Fig. 4 FTIR and Raman spectra of $\delta-\mathrm{MnO}_{2}$ before and after reacting with $\mathrm{As}(\mathrm{II})$ and $\mathrm{Sb}(\mathrm{III})$. IR spectra of $\delta-\mathrm{MnO} \mathrm{O}_{2}$ reacted with (a) $\mathrm{As}(\mathrm{III})$ and (b) Sb(III); Raman spectra of $\delta-\mathrm{MnO}_{2}$ reacted with (c) $\mathrm{As}(\mathrm{II})$ and (d) $\mathrm{Sb}$ (III).

SEM coupled with EDS is a useful technique for identifying mineral structures, wherein major elements on the surface of the tested sample can be determined simultaneously. The highmagnification SEM image (Fig. 5a) reveals that the pristine $\delta$ $\mathrm{MnO}_{2}$ particles were approximately $30-50 \mathrm{~nm}$ in diameter and poorly crystalline. The EDS spectrum showed that pristine $\delta$ $\mathrm{MnO}_{2}$ was predominantly composed of $\mathrm{O}(48.72 \%$, wt) and $\mathrm{Mn}$ $(47.28 \%$, wt) (data not shown). During the reaction of As(III) with $\delta-\mathrm{MnO}_{2}$, the $\delta-\mathrm{MnO}_{2}$ surface structure did not significantly change (Fig. 5b). A similar study also confirmed the particle morphology did not change after $\delta-\mathrm{MnO}_{2}$ reacted with $\mathrm{As}(\mathrm{III})$, as shown in the transmission electron microscopy images. ${ }^{21}$ In addition, negligible amounts of As on the $\delta-\mathrm{MnO}_{2}$ surface were detected using EDS (data not shown), similar to the results of the XPS survey analysis. After reacting with $\mathrm{Sb}(\mathrm{III}), \delta-\mathrm{MnO}_{2}$ exhibited a well-crystallized cubic morphology with large particles (approximately $5.9 \times 3.1 \times 1.5 \mu \mathrm{m}$ ) (Fig. $5 \mathrm{c}$ ) that consisted of elemental $\mathrm{Sb}(54.14 \%, \mathrm{wt}), \mathrm{O}(27.30 \%, \mathrm{wt})$ and $\mathrm{Mn}$ $\left(21.25 \%\right.$, wt) (Fig. 5d). Distinct changes in the $\delta-\mathrm{MnO}_{2}$ morphology and elemental composition were observed during the reaction process with $\mathrm{Sb}$ (III) that were not observed using As(III). These results also suggest that the surface morphology of $\delta-\mathrm{MnO}_{2}$ did not significantly change after becoming passivated during the As(III) oxidation process.
The XRD patterns of the pristine $\delta-\mathrm{MnO}_{2}$ exhibited only two main peaks at $37^{\circ}$ and $66^{\circ}(2 \theta)$ (Fig. 5e), which are characteristic of poorly crystalline phyllomanganates..$^{50,51}$ The XRD patterns were slightly different for $\delta-\mathrm{MnO}_{2}$ before and after reacting with As(III). However, changes in the XRD patterns were apparent after $\mathrm{Sb}$ (III) reacted with $\delta-\mathrm{MnO}_{2}$. The two typical peaks for $\delta$ $\mathrm{MnO}_{2}$ disappeared, and two broad peaks at approximately $27^{\circ}$ $(2 \theta)$ and $54^{\circ}(2 \theta)$ and a sharp peak at $36.3^{\circ}(2 \theta)$ appeared, indicating that the $\delta-\mathrm{MnO}_{2}$ structures were altered after reacting with $\mathrm{Sb}$ (III). A further XRD analysis showed that the newly formed mineral was $\mathrm{Mn}(\mathrm{II})$ antimonate $\left(\mathrm{MnSb}_{2} \mathrm{O}_{6}\right.$, $\mathrm{PDF} 339$ 0980). The results showed a similar crystal structure as $\mathrm{Sb}_{2} \mathrm{O}_{5}$, but low and broad peaks located at $27.5^{\circ}$ and $54^{\circ}(2 \theta)$ were observed. The crystal structure of Mn(II) antimonate could be related to the ratio of $\mathrm{Mn} / \mathrm{Sb}$. A similar study reported by Zhang et al. (2016) also confirmed that the formation of $\mathrm{Mn}$ (II) antimonate during reaction of $\mathrm{Sb}$ (III) with $\mathrm{KMnO}_{4} \cdot{ }^{52}$ The high ratio of $\mathrm{Mn} / \mathrm{Sb}$ contributes to a poorly crystallized structure with low and broad diffraction peaks. In addition, a cubic morphology Mn(II) antimonate with a particle size of 50-150 nm was observed by TEM analysis, which is in accordance with the SEM observations in Fig. 5c. These results suggesting that the $\delta$ $\mathrm{MnO}_{2}$ properties changed more significantly during the reaction with $\mathrm{Sb}(\mathrm{III})$ than with $\mathrm{As}(\mathrm{III})$. 

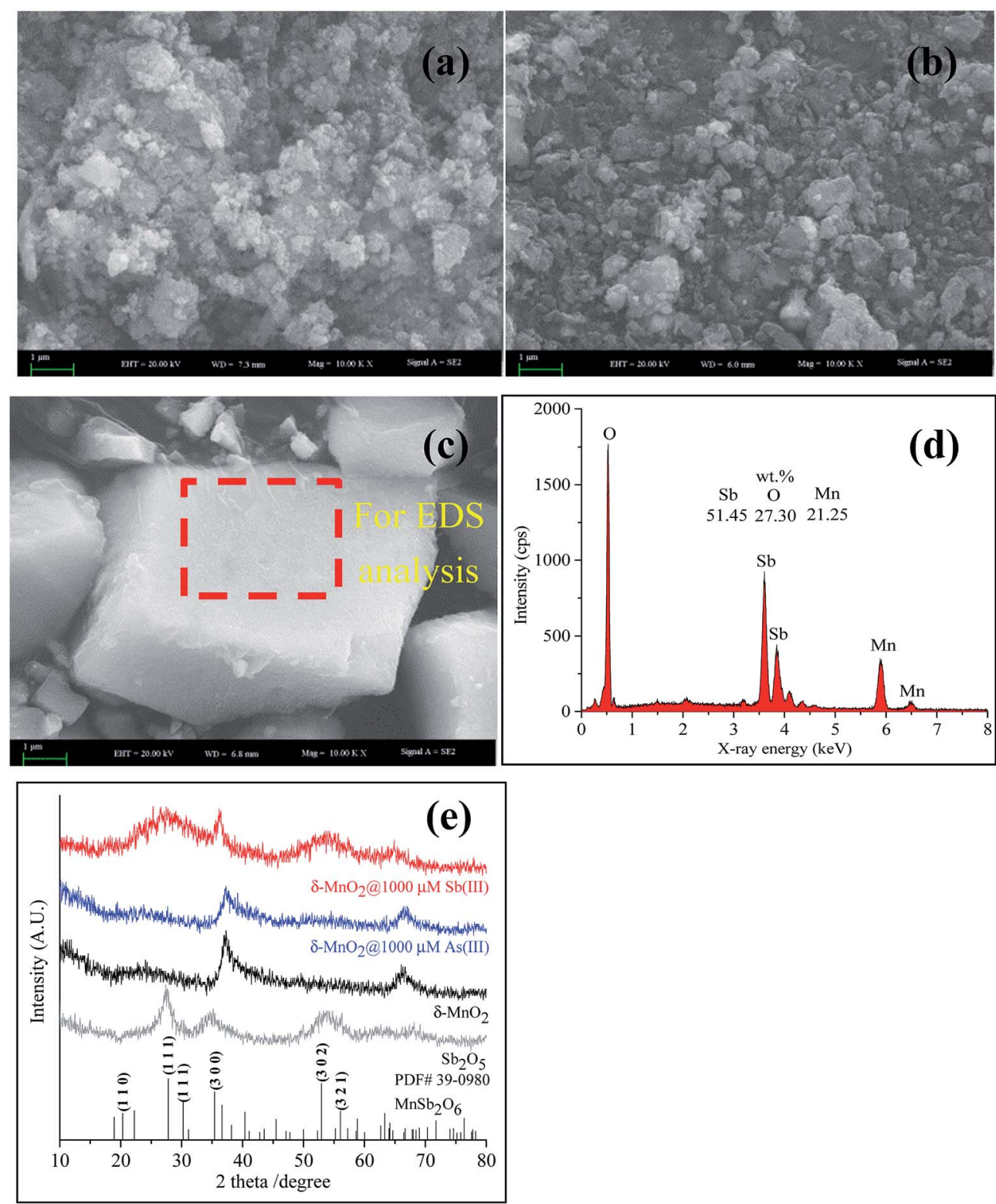

Fig. $5 \mathrm{SEM}$-EDS and XRD of $\delta-\mathrm{MnO}_{2}$ before and after reacting with $\mathrm{As}(\mathrm{III})$ and $\mathrm{Sb}$ (III). (a) SEM of pristine $\delta-\mathrm{MnO}_{2} ;$ (b) $\mathrm{SEM}$ of $\delta-M n \mathrm{O}_{2}$ reacted with $\mathrm{As}(\mathrm{III})$; (c) SEM and (d) EDS of $\delta-\mathrm{MnO}_{2}$ reacted with $\mathrm{Sb}(\mathrm{III})$; (e) XRD patterns of $\delta-\mathrm{MnO}_{2}$ before and after reacting with $\mathrm{As}(\mathrm{III})$ and $\mathrm{Sb}(\mathrm{III})$.

\subsection{Mechanisms of the As(III) and $\mathrm{Sb}(\mathrm{III})$ reactions with $\delta$ - $\mathrm{MnO}_{2}$}

The mechanisms of the As(III) oxidation by $\delta-\mathrm{MnO}_{2}$ were well revealed. Namely, one mole of $\mathrm{As}(\mathrm{III})$ molecules reacted with one mole of $\mathrm{Mn}(\mathrm{Iv})$ reactive sites to generate one mole of $\mathrm{As}(\mathrm{v})$ anions and one mole of $\mathrm{Mn}$ (II) ions (eqn (3)). ${ }^{\mathbf{2 0 , 2 1 , 2 7}}$ In this study, the oxidation rate for $\mathrm{Sb}$ (III) by $\delta-\mathrm{MnO}_{2}$ was faster than that for As(III). A decreasing As(III) oxidation rate was observed after the reaction of 100-1000 $\mu \mathrm{M}$ As(III); the decreased rate was mainly caused by the surface passivation of $\delta-\mathrm{MnO}_{2}$ by secondary products. During the reactions with low concentrations of As(III) (100 and $200 \mu \mathrm{M}$ ), the releases ratio of $\mathrm{As}(\mathrm{V})$ and $\mathrm{Mn}$ (II) from the solution was not equal to the theoretical value of 1 (Fig. S6 $\dagger$ ). The ratio $\mathrm{Mn}(\mathrm{II}) / \mathrm{As}(\mathrm{v})$ was less than 1 , which was primarily attributed to the adsorption of $\mathrm{Mn}$ (II) onto the $\delta-\mathrm{MnO}_{2}$ surface. $\mathrm{Mn}$ (II) could compete with As(v) for the reactive sites, and when the reactive sites were occupied completely by $\mathrm{Mn}$ (II), freshly formed Mn(II) and As(v) tended to completely release into the solution at a mole ratio of $1: 1$. Increasing values of $\mathrm{Mn}$ (II)/As(v) approaching 1 were observed when using high concentrations of $\mathrm{As}(\mathrm{III})$ (500 and $1000 \mu \mathrm{M})$. Previous studies have indicated that the adsorption of $\mathrm{Mn}$ (II) onto the $\delta-\mathrm{MnO}_{2}$ surface is one of the major causes of early $\delta-\mathrm{MnO}_{2}$ passivation. ${ }^{\mathbf{2 1 , 2 6}}$ Meanwhile, less reactive $\mathrm{Mn}$ (III) sites could be formed via comproportionation between the adsorbed $\mathrm{Mn}$ (II) and $\mathrm{Mn}$ (Iv) at the $\delta-\mathrm{MnO}_{2}$ surface, passivating the $\delta-\mathrm{MnO}_{2} \cdot{ }^{21,26}$ The results from the $\mathrm{Mn} 3 \mathrm{~s}$ and $3 \mathrm{p}$ XPS analyses agreed with the increase in the Mn(II) and Mn(III) content on the $\delta-\mathrm{MnO}_{2}$ surface. In addition, the macroscopic and spectroscopic analyses conducted using the SEM-EDS, 
XRD, FTIR and Raman spectra indicated that surface passivation did not significantly change the surface structure of $\delta$ $\mathrm{MnO}_{2}$ during the reaction with As(III).

In contrast to the As(III) oxidation, surface passivation might be not have been a key factor in controlling the oxidation rate of $\mathrm{Sb}$ (III). The surface passivation of $\delta-\mathrm{MnO}_{2}$ by the adsorption of $\mathrm{Mn}$ (II) did not contribute to the remarkable depletion of Mn(Iv) or the change in the $\delta-\mathrm{MnO}_{2}$ structure, but the $\mathrm{Mn}$ (Iv) percentage decreased from $57.6 \%$ to $8.60 \%$ after reacting with $1000 \mu \mathrm{M} \mathrm{Sb}$ (III). Moreover, the increasing Mn(III) content on the $\delta-\mathrm{MnO}_{2}$ surface could also induce surface passivation during the As(III) oxidation process, but the Mn(III) content decreased with the increasing initial $\mathrm{Sb}$ (III) concentration. This observation suggests that $\mathrm{Mn}$ (III) may have had the same ability as $\mathrm{Mn}$ (IV) to oxidize $\mathrm{Sb}$ (III). These results indicated that the surface passivation of $\delta-\mathrm{MnO}_{2}$ might not have occurred during the oxidation of $\mathrm{Sb}(\mathrm{III})$.

According to the XRD results in this study and a previous study, ${ }^{53}$ the reaction of $\mathrm{Sb}(\mathrm{III})$ with $\delta-\mathrm{MnO}_{2}$ can be expressed as shown in eqn (4).

$$
\begin{aligned}
& \mathrm{MnO}_{2(\mathrm{~s})}+\mathrm{Sb}(\mathrm{OH})_{3(\mathrm{aq})}+\mathrm{H}_{(\mathrm{aq})}{ }^{+} \rightarrow \\
& 0.5 \mathrm{Mn}_{(\mathrm{aq})}{ }^{2+}+0.5 \mathrm{MnSb}_{2} \mathrm{O}_{6(\mathrm{~s})}+2 \mathrm{H}_{2} \mathrm{O}_{(\mathrm{aq})}
\end{aligned}
$$

During the $\delta-\mathrm{MnO}_{2}$ reaction with $\mathrm{Sb}(\mathrm{III})$, the transfer of two electrons was responsible for the $\mathrm{Sb}(\mathrm{III})$ oxidation, i.e., one mole of As(III) reacted with one mole of Mn(IV) to produce one mole of $\mathrm{Sb}(\mathrm{v})$ and one mole of $\mathrm{Mn}(\mathrm{II})$. As shown in Fig. S6, $\uparrow$ the $\mathrm{Mn}(\mathrm{II}) / \mathrm{As}(\mathrm{v})$ ratios in solution during the $\mathrm{Sb}$ (III) oxidation were higher than those during the As(III) oxidation. According to the two-electron transfer reaction, the oxidation of one mole of $\mathrm{Sb}(\mathrm{III})$ produces one mole of $\mathrm{Sb}(\mathrm{v})$ and $\mathrm{Mn}(\mathrm{II})$, but the formation of one mole of precipitated $\mathrm{Mn}$ (II) antimonate requires one mole of $\mathrm{Sb}(\mathrm{v})$ and 0.5 mole of $\mathrm{Mn}$ (II) (eqn (4)). The unprecipitated $\mathrm{Mn}$ (II) could be absorbed onto the $\delta-\mathrm{MnO}_{2}$ surface or released into the solution. At low $\mathrm{Sb}(\mathrm{III})$ concentrations, the low values of $\mathrm{Mn}(\mathrm{II}) / \mathrm{Sb}(\mathrm{v})$ were attributed to the adsorption of $\mathrm{Mn}(\mathrm{II})$ onto the $\delta-\mathrm{MnO}_{2}$ surface. Due to the decrease in the number of $\mathrm{Mn}$ (Iv) reactive sites, the adsorption of $\mathrm{Mn}$ (II) could be inhibited when reacting with high concentrations of $\mathrm{Sb}(\mathrm{III})$ (from 200 to $1000 \mu \mathrm{M}$ ). Interestingly, the maximum $\mathrm{Mn}(\mathrm{II}) / \mathrm{Sb}(\mathrm{v})$ ratios were observed in the presence of $500 \mu \mathrm{M} \mathrm{Sb}(\mathrm{III})$. This result was ascribed to the adsorption of $\mathrm{Mn}$ (II) onto the newly formed $\mathrm{Mn}$ (II) antimonate precipitates; this phenomenon reduced the concentration of Mn(II) in the solution. Previous studies have suggested that $\mathrm{Mn}$ (II) antimonate can effectively adsorb a series of divalent metals including $\mathrm{Sr}(\mathrm{II}), \mathrm{Co}(\mathrm{II}), \mathrm{Ca}(\mathrm{II})$ and $\mathrm{Ba}(\mathrm{II}) .^{\mathbf{5 2 , 5 4}}$

In addition, $\mathrm{Sb}(\mathrm{v})$ was also released into the solution. This release was attributed to two causes. First, during the $\mathrm{Sb}$ (III) oxidation process, $\mathrm{Sb}(\mathrm{v})$ could adsorb onto the surface of $\delta$ $\mathrm{MnO}_{2}$. A similar study reported by Wang et al. (2012) suggested that the oxidation of $\mathrm{Sb}(\mathrm{III})$ by manganite $(\gamma-\mathrm{MnOOH})$ occurred within $10 \mathrm{~min}$, and $\mathrm{Sb}(\mathrm{v})$ was absorbed by forming inner-sphere complexes at the manganite surface. ${ }^{55}$ Second, the dissolution of the Mn(II) antimonate precipitates might have contributed to the release of $\mathrm{Sb}(\mathrm{v})$ into the solution.

\section{Conclusions}

In geochemical processes, the migration and transformation of $\mathrm{Sb}$ and As are critically determined by minerals present in the environments. Poorly crystalline phyllomanganates such as $\delta$ $\mathrm{MnO}_{2}$ can act as powerful oxidizers and scavengers for $\mathrm{Sb}$ (III) and As(III) in these environments. Therefore, understanding the retention mechanism between $\delta-\mathrm{MnO}_{2}$ and $\mathrm{Sb}$ (III) or $\mathrm{As}$ (III) has important environmental implications. In this study, As(III) and $\mathrm{Sb}$ (III) were both oxidized by $\delta-\mathrm{MnO}_{2}$, but the oxidation rate of $\mathrm{Sb}$ (III) was more rapid than that of As(III). The decreasing As(III) oxidation rate was primarily attributed to the surface passivation of $\delta-\mathrm{MnO}_{2}$ by the adsorption of $\mathrm{Mn}$ (II) and the formation of $\mathrm{Mn}(\mathrm{III})$. In contrast, the surface of $\delta-\mathrm{MnO}_{2}$ was not significantly passivated during the $\mathrm{Sb}$ (III) oxidation. The rapid oxidation of $\mathrm{Sb}$ (III) by $\delta-\mathrm{MnO}_{2}$ favors the precipitation of $\mathrm{Mn}$ (II) antimonate rather than the complete release of $\mathrm{Sb}(\mathrm{v})$ into the solution. Thus, the difference between the $\mathrm{Sb}$ (III) and As(III) oxidation mechanisms in this study facilitated a better understanding of the environmental behavior of $\mathrm{Sb}$ and $\mathrm{As}$ on $\mathrm{Mn}$ oxide surfaces in aquatic environments.

\section{Acknowledgements}

This work was financially supported by the Shandong Province Natural Science Foundation (Grant ZR2016DQ08), the CPSFCAS Joint Foundation for Excellent Postdoctoral Fellows (Grant 2016LH0048), the China Postdoctoral Science Foundation funded project (Grant 2016M600829), and the National Natural Science Foundation of China (Grant 51678315).

\section{References}

1 D. Zhang, X. Pan, G. Mu and J. Wang, J. Appl. Phycol., 2010, 22, 479-488.

2 S. Wang, D. Zhang and X. Pan, Ecotoxicol. Environ. Saf., 2012, 84, 104-111.

3 L. Paoli, E. Fiorini, S. Munzi, S. Sorbo, A. Basile and S. Loppi, Chemosphere, 2013, 93, 2269-2275.

4 J. Warnken, R. Ohlsson, D. T. Welsh, P. R. Teasdale, A. Chelsky and W. W. Bennett, Chemosphere, 2017, 180, 388-395.

5 S. C. Wilson, P. V. Lockwood, P. M. Ashley and M. Tighe, Environ. Pollut., 2010, 158, 1169-1181.

6 S. K. Gupta and K. Y. Chen, J. - Water Pollut. Control Fed., 1978, 50, 493-506.

7 S. Dixit and J. G. Hering, Environ. Sci. Technol., 2003, 37, 4182-4189.

8 J. Jiang, I. Bauer, A. Paul and A. Kappler, Environ. Sci. Technol., 2009, 43, 3639.

9 T. Gebel, Chem.-Biol. Interact., 1997, 107, 131.

10 B. A. Manning and S. Goldberg, Environ. Sci. Technol., 1997, 31, 2005-2011.

11 H. W. Nesbitt, G. W. Canning and G. M. Bancroft, Geochim. Cosmochim. Acta, 1998, 2097-2110.

12 D. W. Oscarson, P. M. Huang, C. Defosse and A. Herbillon, Nature, 1981, 291, 50-51. 
13 P. Z. Ray and H. J. Shipley, RSC Adv., 2015, 5, 29885-29907.

14 F. L. Fu, Z. H. Cheng and J. W. Lu, RSC Adv., 2015, 5, 8539585409.

15 D. W. Oscarson, P. M. Huang, W. K. Liaw and U. T. Hammer, Soil Sci. Soc. Am. J., 1983, 47, 644-648.

16 R. M. Weaver and F. M. Hochella, Am. Mineral., 2003, 88, 2016-2027.

17 K. D. Kwon, K. Refson and G. Sposito, Geochim. Cosmochim. Acta, 2010, 74, 6731-6740.

18 D. M. Sherman and C. L. Peacock, Geochim. Cosmochim. Acta, 2010, 74, 6721-6730.

19 J. P. Lefkowitz and E. J. Elzinga, Environ. Sci. Technol., 2015, 49, 4886-4893.

20 B. A. Manning, S. E. Fendorf, B. Bostick and D. L. Suarez, Environ. Sci. Technol., 2002, 36, 976.

21 B. J. Lafferty, M. Ginder-Vogel and D. L. Sparks, Environ. Sci. Technol., 2010, 44, 8460-8466.

22 G. Landrot, M. Ginder-Vogel, K. Livi, J. P. Fitts and D. L. Sparks, Environ. Sci. Technol., 2012, 46, 11594-11600.

23 J. F. Li, H. Gyoten, A. Sonoda, Q. Feng and M. Xue, RSC Adv., 2017, 7, 1490-1497.

24 H. Wang, D. Zhang, S. Mou, W. Song, F. A. Al-Misned, M. M. Golam and X. Pan, Chemosphere, 2015, 136, 102-110.

25 L. Wang and H. Cheng, Environ. Sci. Technol., 2015, 49, 34733481.

26 B. J. Lafferty, M. Gindervogel, M. Zhu, K. J. T. Livi and D. L. Sparks, Environ. Sci. Technol., 2010, 44, 8467.

27 C. Tournassat, L. Charlet, D. Bosbach and A. Manceau, Environ. Sci. Technol., 2002, 36, 493.

28 M. Zhu, K. W. Paul, J. D. Kubicki and D. L. Sparks, Environ. Sci. Technol., 2009, 43, 6655.

29 B. J. Lafferty, M. Gindervogel and D. L. Sparks, Environ. Sci. Technol., 2011, 45, 9218-9223.

30 S. E. Fendorf and R. J. Zasoski, Environ. Sci. Technol., 1992, 26, 79-85.

31 Z. Wang, S. W. Lee, P. Kapoor, B. M. Tebo and D. E. Giammar, Geochim. Cosmochim. Acta, 2013, 100, 24-40.

32 M. Villalobos, B. Toner, J. Bargar and G. Sposito, Geochim. Cosmochim. Acta, 2003, 67, 2649-2662.

33 P. G. Brewer and D. W. Spencer, Limnol. Oceanogr., 1971, 16, 107-110.

34 D. Fullston, A. D. Fornasiero and J. Ralston, Langmuir, 1999, 15, 4530-4536.
35 J. P. Nair, R. Jayakrishnan, N. B. Chaure, A. Lobo, S. K. Kulkarni and R. K. Pandey, Thin Solid Films, 1999, 347, 39-45.

36 V. A. Drits, E. Silvester, A. I. Gorshkov and A. Manceau, Am. Mineral., 1996, 82, 946-961.

37 E. Silvester, A. Manceau and A. V. Drits, Am. Mineral., 1997, 82, 962-978.

38 C. L. Peacock and D. M. Sherman, Chem. Geol., 2007, 238, 94-106.

39 Z. Wang and D. Giammar, ACS Symposium Series, Advances in the Environmental Biogeochemistry of Manganese Oxides, 2015, ch. 2, vol. 1197, pp. 29-50.

40 A. L. Foster Jr, G. E. Brown and G. A. Parks, Geochim. Cosmochim. Acta, 2003, 67, 1937-1953.

41 A. Manceau, M. Lanson and N. Geoffroy, Geochim. Cosmochim. Acta, 2007, 71(1), 95-128.

42 P. S. Nico and R. J. Zasoski, Environ. Sci. Technol., 2001, 35, 3338-3343.

43 K. J. Livi, B. Lafferty, M. Zhu, S. Zhang, A. C. Gaillot and D. L. Sparks, Environ. Sci. Technol., 2012, 46, 970-976.

44 W. Si, Y. Wang, Y. Peng, X. Li, K. Li and J. Li, Chem. Commun., 2015, 51(81), 14977-14980.

45 X. Ge, J. Liu, X. Song, G. Wang, H. Zhang, Y. Zhang and H. Zhao, Chem. Eng. J., 2016, 301, 139-148.

46 R. Liu, F. Liu, C. Hu, Z. He, H. Liu and J. Qu, J. Hazard. Mater., 2015, 300, 847-854.

47 R. M. Potter and G. R. Rossman, Am. Mineral., 1979, 64, 1199-1218.

48 C. Julien, M. Massot, R. Baddour-Hadjean, S. Franger, S. Bach and J. P. Pereira-Ramos, Solid State Ionics, 2003, 159, 345-356.

49 N. Mironova-Ulmane, A. Kuzmin and M. Grube, J. Alloys Compd., 2009, 480, 97-99.

50 M. Villalobos, B. Lanson, A. Manceau, B. Toner and G. Sposito, Am. Mineral., 2006, 91, 489-502.

51 V. A. Drits, B. Lanson and A.-C. Gaillot, Am. Mineral., 2007, 92, 771-788.

52 L. Zhang, J. Wei, X. Zhao, F. Li, F. Jiang, M. Zhang and X. Cheng, Chem. Eng. J., 2016, 302, 733-743.

53 N. Belzile, Y. W. Chen and Z. Wang, Chem. Geol., 2001, 174, 379-387.

54 M. Abe, J. Inorg. Nucl. Chem., 1979, 41, 85-89.

55 X. Wang, M. He, C. Lin, Y. Gao and L. Zheng, Chem. Erde, 2012, 72, 41-47. 